\title{
Design Thinking as Meaning Creation: The Case of Descomplica
}

\author{
Design Thinking como Criação de Significado: O Caso do Descomplica
}

\section{ABSTRACT}

Context: the design language was introduced to innovation management as a mechanism to increase creativity, given the predominance of an economic rationality in the innovation theory and practice. Among the design thinking discourse, meaning innovation gained relevance in postindustrial societies. Objective: explore the adherence of Descomplica strategy to the meaning innovation model. Method: an exploratory survey with a qualitative approach and a narrative method was carried out. Results: the data collected shows that the company does have a strategy to build and consolidate an emotional relationship with its users. This emotional connection can be perceived in students' narratives, mainly when they came from public schools. Results also brought evidence that traditional education methods can be threatened by EdTech, mainly in environments where regulatory controls are weak. Conclusion: even though meaning innovation proved to be effective from the point of view of Descomplica's strategy, it cannot be considered a radical innovation in the sense attributed by sustainability-oriented innovation theory. The results reinforce the urgency to discuss, from organizational and educational perspectives, the impacts of online platforms in Brazilian students' perceptions, behaviors, and capabilities development.

Keywords: design thinking; meaning innovation; disruptive innovation; online education platforms; EdTech.

\section{RESUMO}

Contexto: a linguagem do design foi introduzida na gestão de inovação como um mecanismo para aumentar a criatividade, dada a predominância de uma racionalidade econômica na teoria e na prática da inovação. Entre os discursos do design thinking, a inovação por significado ganhou relevância nas sociedades pós-industriais. Objetivo: explorar a aderência da estratégia do Descomplica ao modelo de inovaçáo por significado. Método: foi realizado um estudo exploratório com abordagem qualitativa e método de análise das narrativas. Resultados: os dados coletados mostram que a empresa possuía uma estratégia para construir e consolidar um relacionamento emocional com seus usuários. Essa conexão emocional pode ser percebida nas narrativas dos alunos, principalmente quando eles estudaram em escolas públicas. Os resultados evidenciaram que os métodos tradicionais de educação podem ser ameaçados pelas EdTechs, principalmente em ambientes onde os controles regulatórios são fracos. Conclusáo: embora a inovação por significado tenha se mostrado eficaz do ponto de vista da estratégia do Descomplica, ela náo pode ser considerada uma inovação radical no sentido atribuído pela inovação orientada pela sustentabilidade. Os resultados reforçam a urgência de discutir, do ponto de vista organizacional e educacional, os impactos das plataformas on-line.

Palavras-chave: design thinking; significado; inovaçâo disruptiva; plataformas de educação on-line; EdTech.

\begin{tabular}{|c|c|c|c|c|c|c|c|c|c|}
\hline & 1 & 2 & 3 & 4 & 5 & 6 & 7 & 8 & 9 \\
\hline $1^{\text {st }}$ round & 9 & $\stackrel{9}{2}$ & & & & & & & \\
\hline $2^{\text {nd }}$ round & 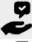 & (x) & & & & & & & \\
\hline $3^{\text {rd }}$ round & $y$ & & & & & & & & \\
\hline
\end{tabular}




\section{INTRODUCTION}

The theory and practice of design can be categorized, in a meta-analyses perspective, in three distinct but related phases: (a) the constitution of design as a field of knowledge, with a proper language and discourse; (b) design management, when designers became aware of the opportunity to convert their body of knowledge into a tool that could be managed and applied in organizations; (c) design thinking (DT), when the design method of thought was translated into a systematic process that could be applied by any managers to solve firm's business problems. It was in this 3rd phase, after the mid-2000, when the design discourse was incorporated by business administration - more specifically by innovation management - that the DT gained popularity among managers (JohanssonSköldberg, Woodilla, \& Çetinkaya, 2013).

Figueiredo (2009) argues that innovation “... means blending several different types of knowledge and transforming them into new products and useful services to the market or to the society" (Figueiredo, 2009, p. 31). From a cognitive perspective, innovation can be interpreted as a social process of meaning creation (Cohen \& Levinthal, 1990; Nonaka \& Takeuchi, 1995). Converging these two concepts, to 'blend' and to 'transform' types of knowledge into products may be considered the way that languages are interpreted and translated in a business environment, so that individuals get interested and ascribe value to a company' proposal. So, to innovate at an organizational level is to create a relation or purpose between products and consumers.

Krippendorff (1989) claims that to develop or to transform meaning is exactly the purpose of design, being one of the main functions that can be associated to the design discourse (Johansson-Sköldberg et al., 2013). It is not by chance that the design is considered a strategic resource for business model innovation-driven strategies (Teece, 2010). In the context of this study, the word 'purpose' is linked to the definition of meaning as described by Roberto Verganti, whose studies play a theoretical lenses role in this article.

In normative business ethics studies, a change in meaning is associated with paradigmatic or epistemological changes toward ecocentric economic systems (Allen, Cunliffe, \& Easterby-Smith, 2019). Education is considered a fundamental mechanism to produce a self-reflexive, transdisciplinary, and critical interpretation of business-asusual cognitive frame and taboos (Gröschl \& Gabaldon, 2018), such as the association of well-being to the possession of material goods (Painter-Morland, Demuijnck, \& Ornati, 2017). In critical management studies, the predominance of an economic rationality is related to the elimination of ethical concerns in strategy theory and practice (Elms,
Brammer, Harris, \& Phillips, 2010), and meritocracy is associated to social Darwinism ideology that prevails in neoliberal capitalism (Gantman, 2019).

In DT literature and practice, especially in management, predominates a problem-solving orientation. Meaning innovation, on the other hand, may generate value through more intangible benefits, linked to symbolic and emotional relationships with products and services (Dell'Era \& Verganti, 2007). Companies successful in this process usually hold tacit knowledge and internal methodologies that are difficult to copy, and consequently to analyze using a reductionist epistemology (Dell'Era \& Verganti, 2007). That tacit capability also applies to existing markets, and companies able of surviving and prospering in such environments are called serial innovators (Vojak, Price, \& Griffin, 2012). As pointed by Verganti (2017), a meaning strategy must be deployed first, giving directions for the implementation of innovation strategies.

This study is aligned with the field of innovation management, specifically to the DT theory and practice, using the hermeneutics as an epistemological approach. As such, DT considers innovation as a process for interpreting and projecting new meanings for products and services within a given socio-technical context (Verganti \& Öberg, 2013). To explore a meaning strategy, we will analyze the case of Descomplica, a company based in Rio de Janeiro, Brazil, which offers online educational content at low prices to prepare students for college admission exams. Given the fact that we are using DT to analyze Descomplica (a portal), it is important to clarify that our focus is the process of innovation, not the tool or the technology.

The research problem emerged from the curiosity provoked by intriguing questions. As other technology intermediaries, Descomplica could have been designed to provide, at affordable prices, online educational content to students when they want, in any place, and without delay, focusing its value proposition on autonomy (Kim, Park, \& Lee, 2019). Besides, Descomplica could adopt some characteristics of gig platforms regarding labor relationships, such as freelancer teachers or on-demand content producers (Vallas \& Schor, 2020). Therefore, how Descomplica, even though it was a virtual platform, developed new meaning to connect teachers with students' needs and emotions?

According to Hesse, Dann, Braesemann, and Teubner (2020), "the more a platform's value proposition hinges on social interactions, the more important it is to provide expressive trust cues" to customers (Hesse, Dann, Braesemann, \& Teubner, 2020, p. 5146). Thus, was Descomplica's narrative designed to fill students' expectations regarding the capabilities demanded by job markets in contemporary capitalism, such as meritocracy, entrepreneurship, freelancing, and project-based work 
skills (Ratten \& Usmanij, 2020), by-passing, as is usual in technology intermediaries (Frenken, Vaskelainen, Fünfschilling, \& Piscicelli, 2018), federal regulations regarding curriculum content?

Finally, can Descomplica, given its flexibility, agility, and reach, impose serious threats to regulated education institutions, as did other startups that emerged from the digital transformation of different economic sectors? In fact, at the time the field research was carried out, Descomplica did not manifest the intention to enter the regulated education market. In 2020, however, Descomplica decided to offer undergraduate online courses, building upon the communication skills developed in preparatory courses (Lima, 2020).

According to Magistretti, Dell'Era, and Verganti (2020), cultural insights "... is the capacity to spot and sense emerging cultural trends" (Magistretti, Dell'Era, \& Verganti, 2020, p. 737). One of the most impactful trends is the proliferation of technology platforms in almost all economic sectors, including EdTechs (Cornelissen \& Cholakova, 2019). Recent studies have highlighted the virtues of the gig economy in education, completely disregarding the impacts of freelance relationships on the teaching profession and the curriculum content design (Olga, Julian, \& Vladik, 2019). Nonetheless, the use of meaning innovation to critically evaluate online service platforms, especially in the Brazilian education context, remains underexplored in the scientific literature (De Goey, Hilletofth, \& Eriksson, 2019).

We acknowledge that the case of Descomplica could have been analyzed using other theoretical lenses applied in the innovation process management field, such as paradigmatic innovation (Utterback, 1994), innovation by recombination (Griffith, Lee, \& Straathof, 2017), and business model innovation (Teece $\&$ Linden, 2017). The last also discusses the resignification construct. But, given the context portrayed above, we formulate the following research question: To which extend can Verganti's innovation model explain Descomplica's strategy and success on aligning its branding meaning to its perceived meaning? The primary objective of this research is to explore the adherence of Descomplica's strategy to the meaning innovation model as defined by Verganti and Öberg (2013). The secondary objectives are to map Descomplica's meaning development process, and to identify synergies between the meaning proposed by Descomplica and the meaning perceived by students.

This article's singular contribution to DT theory and practice is to explore the relationship between the meaning created in on-demand education platforms and the symbolic impact on students' subjectivity regarding education. Another important contribution to meaning innovation theory and practice was to apply a survey roadmap workshop conducted by Verganti and Öberg (2017) that, to the best of our knowledge, is still unexplored in the scientific literature. Although the impact of the gig economy on labor relationships is a hot topic in education (Means, 2018), we do not discuss these effects in this article.

\section{THEORETICAL BACKGROUND}

\section{Design thinking as an innovation management method}

Innovation, as systematic practice in economic systems, was first emphasized in the seminal theory of Joseph Schumpeter, who was nicknamed the prophet of innovation (McCraw, 2007). By introducing innovation, business entrepreneurs generate a creative destruction mechanism that drives capitalism's dynamic forces (Schumpeter, 1934). As science and technology became a central aspect for policymakers during the first half of the 20th century, innovation studies "gained crescent attention from researchers within economics, management and sociology, interested in exploring the economic and social aspects of innovation and technology diffusion" (Fagerberg, Fosaas, Bell, \& Martin, 2011, p. 897).

Since then, innovation is increasingly regarded as the fundamental cause of a country's socio-economic wealth and of the development of world-class business firms (Organization for Economic Co-operation and Development [OECD], 2005). Following the thoughts of the prophet, the new-Schumpeterian school laid the foundations of innovation economics (Dosi, 1982). In the management realm, the innovation field can be traced back to the seminal study of Christopher Freeman (1974). As a problem-solving tool, innovation aimed at changing the drivers that lead to cost leadership or differentiation (Freeman \& Soete, 2007). According to the Oslo Manual (OECD, 2005), innovation "is the implementation of a new or significantly improved product (good or service), or process, a new marketing method, or a new organizational method in business practices, workplace organization or external relations" (OECD, 2005, p. 46).

From a socio-technical system perspective, radical innovations bring along new technological paradigms, opening the potential for additional changes, or incremental innovations, which transform and capture value from the potential open by radical innovations (Savage, Geissdoerfer, Kharrazi, \& Evans, 2019). Without radical innovations, incremental innovations do not have a fertile path to explore. But without incremental innovations, the potential created by radical changes is not fully developed (Norman \& Verganti, 2014). Different from radical innovation, which involves high uncertainty, a long diffusion process, and a 
complete reconfiguration of production chains, disruptive innovation is "a process by which a product or service initially takes root in simple applications at the bottom of a market - typically by being less expensive and more accessible and then relentlessly moves upmarket, eventually displacing established competitors" (The Christensen Institute, 2021, online).

The mainstream innovation theories follow an economic rationality that leads to conspicuous consumption, accelerated depreciation as in fast fashion models, and depletion of natural resources and biodiversity destruction, effects that are incompatible with the transition to sustainability (Siqueira \& Pitassi, 2016). Sustainabilityoriented innovations (SOI), in which radical innovations play a fundamental role, on the contrary, involve "... making intentional changes to an organization's philosophy and values, as well as to its products, processes or practices to serve the specific purpose of creating and realizing social and environmental value in addition to economic returns" (Adams, Jeanrenaud, Bessant, Denyer, \& Overy, 2015, p. 181).

Because of its technicist approach, some scholars defended the need for a design perspective to bring more creativity to the innovation process at an organizational level (Johansson \& Woodilla, 2009). Herbert Simon (1969) was one of the first academics who researched the design as an approach to artifacts creation (Johansson-Sköldberg et al., 2013). The term 'design thinking' became popular by IDEO, a design consulting company (Brown, 2008). The DT methodology searches for the solution of problems through inspiration, ideation, and prototyping phases (Brown, 2008).

The most known application of DT is the usercentered design (UCD), that is, the design focused on the user experiences. However, this approach is better applied for incremental innovations, once they contribute to the improvement of existing products and services' usability (Norman \& Verganti, 2014). Therefore, UCD does not create completely new products and services, but solves existing problems by focusing on improvement opportunities for current users. Based on these arguments, DT can be considered a 'demand pull innovation,' as categorized in the innovation literature (Mowery \& Rosenberg, 1979).

Johansson-Sköldberg, Woodilla, and Çetinkaya (2013), in a theoretical effort to connect the DT as used in management to the wider and more robust models, methodologies, and languages of 'designerly thinking' traditions, explained how DT instrumented the way a designer thinks, creating a systematic method that could be applied by managers without a design background. These authors divided the publications that use the DT approach into three main concepts that encompass all lines of action of the design discourse (rationalist, positivist, hermeneutic).

According to Johansson-Sköldberg et al. (2013), there are three subclasses of designerly thinking (first category): (a) rationalism - study of design as a science for the creation of artifacts; (b) pragmatic or practical perspective - study of design for the practice of the design to solve problems in existing products; (c) hermeneutics - study of the design to create new meanings and intentions of utilization, being more abstract and conditioned to the type of emotional relationship that individuals may have with things.

Designerly thinking may be used both for improving the adaptability of the product functions or aesthetics (UCD), by means of incremental innovations, and for changes in meaning and intention of use of the product (meaning strategy or design-driven innovation), by means of radical innovations (Norman \& Verganti, 2014). In summary, the wide concept encompasses the full discourse of design, including the meaning (Kolko, 2015), even though the terminology DT is mostly known in managements as a problem-solving method (UCD).

\section{Meaning innovation}

When considering the strategy for meaning innovation, the economic rationality of innovation is less adequate, since the relations created between products and consumers (meanings) depend on acting on the cultural context (Verganti \& Öberg, 2013). So, there is not a common meaning applicable to all things, but different interpretations generated within complex socio-technical systems. Meaning innovation is a change in the purpose, in the 'why' people decide to use some products and services, and not only in the 'how' these products and services are used (Verganti, 2017). Meaning strategies are not a linear path of solutions, because, instead of solving the problem, which leads to temporary financial gains, they reconfigure the problem, promoting a cycle of reinterpretation by opening new insights (Verganti, 2008). Changing 'why' people use a product or service opens new avenues to change the 'how' people can use products and services, namely incremental innovations (Verganti \& Öberg, 2013).

In the post-industrial economy, not only users, but the whole network of stakeholders has increased the interest in the semantic value of a company (Adams et al., 2015). It is thus important for managers to understand that the meaning of a company is not built only by technology and by the design product or service, but by the design of the whole company. That is, its set of relationships with suppliers, employees, users, financial entities, government, etc. (Battistella, Biotto, \& Toni, 2012). 
According to Verganti and Öberg (2013), meaning innovation is the result of a research process where languages and meanings are shared with companies and external interpreters. The capability to interpret socio-cultural phenomena is abstract and differs, varying and being influenced according to each one's history, repertoire, and vision of the world. The changes generated by meaning innovations are radical, because they change the market and the way to consume, depending, in some measure, on changes in the socio-technical system (Verganti, 2006). According to these authors, the meaning propositions are born from inside the organization. Then, it is the company, after an internal creative development exercise, which proposes the new meaning to the market, and not the opposite way (Verganti, 2016).

It is important to highlight that innovations by meaning may develop new technologies or improve existing ones. In the case of Descomplica, we will explore the meaning innovation in an education organization, an already existent market. Kim and Maubourgne (2005) called this type of innovation 'reconstructionist,' for it breaks the current relationship and builds a new one.

\section{METHODOLOGY}

This research adopts a qualitative approach, with an exploratory aim, and an inductive interpretation method. We classify the research as exploratory because the problem investigates a complex relationship, and yet not clearly defined, between meaning innovation and the subjectivity of users of online platform intermediaries. The narrative analysis method was used to reach the aimed results presented in the introduction session. The use of a case study is a survey strategy that tries to understand the phenomena dynamics in specific contexts, and allied with the inductive theory, builds a good methodology to be applied in new academic concepts, which require an exploratory perspective (Eisenhardt, 1989).

The criteria used for selecting Descomplica for the case study was the fact that the company states to have a position that differs from other online education organizations, prioritizing the emotional relationship with students, instead of working on the valorization or acknowledgment of its brand. It should be highlighted that Descomplica did not state having used the meaning innovation strategy in any document or during the interviews.

Data collection occurred in November and December of 2017 and was split into two phases. In the first phase, open interviews were carried out with five of the main managers who influenced the content and the strategies used by the company: (a) the manager responsible for new business development; (b) one of the partners, which is head of education and operations, and a teacher; (c) the marketing and operations VP; (d) the marketing and audiovisual production manager; (e) the marketing manager and a teacher. In the second phase, we carried out 20 semistructured interviews with Descomplica users (students).

Regarding the number of students interviewed, the selection criteria were to get certain heterogeneity among the origins of their education in terms of public schools or private schools. However, over the interviews, we identified a convergence between the reports of the students who opt for the more disputed courses or are preparing themselves for the college admission exams for more than one year, independently of their education origin. Due to this, the student sample was separated into these three categories. We stop interviewing students based on a theoretical saturation criterion.

According to Adams, Smart, and Huff (2017), in the management field the so-called grey literature is an important source of evidence when research must deal with a phenomenon still without a consolidated body of knowledge in the scientific literature, yet emerging in the practice of managers, as is the case of meaning innovation as interpreted is this article. Following this rationale, data collection was based on two different interview scripts, one for the managers and teachers (phase 1), and the other for students (phase 2). We decide to use the same interview scripts for managers and teachers because at the time the field research was carried out, they perform both functions. In relation to students, the questions were designed to capture their subjective experience with Descomplica.

The data interpretation was systematized in three steps, aimed at: (a) exploring the adherence of Descomplica strategy to the 'meaning strategy'; (b) evaluating, according to the managers' perceptions, what leads the users to subscribe to Descomplica; (c) identifying the meaning of the company to users, mainly considering that the company depends on the student initiative to pay for their classes (subscriptions), even if Descomplica is not part of the formal educational system. The data was treated by the Atlas.ti software, using the codification method proposed by Friese (2014): noticing things; collecting things; thinking about things (NCT).

The unit of analysis for this article was the meaning creation process that drove Descomplica innovation strategy. To interpret the data, this study applied a structured and rational process, following Verganti and Öberg's (2017) recommendations. To answer the main objective, the interpretation of the narrative is presented in Figure 3. In this process, we tried to categorize the innovation, separating meaning from incremental innovation, as proposed by Verganti's framework (Figure 3). The coding process to identify the incremental innovation from the manager's perspective is partially presented in Figure 4. 
The questions for the managers in the interview script were classified according to the meaning innovation process idealized by Verganti and Oberg in a workshop with managers (Verganti \& Öberg, 2017). The script was organized into four categories: (a) awakening: calling attention to the necessity of a change in meaning; (b) preemptying: internally think about what this change would be and prepare the proposal; (c) criticizing: validate the proposal for change with individuals both inside and outside the organization; (d) embodying: congregate and spread the change inside the organization by means of actions so that the team incorporates the new meaning to their beliefs. To help the comparison between the meaning innovation theory and the case analysis, the results and discussion section was organized in accordance with these four steps.

Based on the constructs obtained in the managers' narratives (accessibility, epiphany, and humanization), a second coding process aimed at identifying the meaning strategy from students' perspective, partially depicted in Figure 5, was made. To perceive possible differences in students' perception, data were interpreted considering students' educational background. During this coding process the epiphany and the hero teacher constructs emerged inductively from the narratives.

Finally, and to answer the second intermediate objective, we confronted the results obtained from managers with the results obtained with users. This analysis can be seen in Figure 6. To help readers, codes were classified in order of importance, as practical problem solving as the basic motivation, and emotional meaning reinterpretation at the top of codes categorization.

To assure the quality and validity of data collected and of results obtained, we took the following precautions (Creswell, 2003; Denzin \& Lincoln; 1994; Guba \& Lincoln, 1989; Miles \& Huberman, 1994): (a) problematize the phenomenon to allow data collection in the field and its refutability; (b) select a theoretical framework that allowed an adequate framing of the problem and a dialogue with the data collected in the field; (c) apply the narrative method to allow a hermeneutics epistemology; (d) provide a rich and detailed description of data collection procedures and the coding process; (e) organize the discussion sections in accordance to research objectives; (f) triangulate the evidence collected within the chosen method by confronting the managers' narratives with the students' narratives; (g) triangulate the concepts of meaning and radical innovation in DT theory with the concepts of meaning and radical innovation of SOI discussions; (h) triangulate researchers' interpretations through a consensus-building process; (i) critically reflect on the factors that could influence our interpretation and results.

\section{RESULTS AND DISCUSSION}

Traditional or elite college admission preparatory courses focus on exclusivity. They work so that their institution presents a strong brand, which could attract those students who aim for above-average results (Ruvolo, 2015). In 2011, Marco Fibhen, a physics teacher who used to work in a traditional college admission preparatory course, question this elitist approach. He launched Descomplica, a digital platform with preparation content for college admission exams, which is an important step for students who intend to enter a public university, which in most cases offers the best education in Brazil.

Before becoming a technological platform, the content produced by Descomplica's founder was sold through diskettes on newsstands. Marco's idea was always to offer quality content for as many people as possible, allowing them to have access opportunities for enrolling in good colleges. Users stayed an average of 80 minutes per website visit in 2015, accessing (logging in) it every three days. According to statistics provided by Ruvolo (2015), $78 \%$ of enrolled students who attended entrance exams outperform the national average results. They charged around R\$ 20 monthly (US\$ 4) for the Descomplica Top Program, much less than traditional preparation schools' fees, which could reach more than R $\$ 3.000 /$ month (US\$ 600). The cost of internet connections with Descomplica app, which could be significant in countries like Brazil, was not included in students' education costs.

Besides democratizing access, Descomplica aimed at producing education differently, prioritizing not only the transmission of content but also the participation of users. The evidence collected, partially resumed in Table 1 , showed that Descomplica tried to speak the same language as the youngsters, and to build a more pleasant experience for the students by using funny videos.

\section{The coding process}

Figure 1 resumes the coding process applied to interpret data collected from Descomplica managers' narratives. Due to signs of probable tuning between the emotional relationship proposed by the company and the emotional relationship perceived by the users, we can assume that Descomplica's meaning model is the OPPORTUNITY creation model. According to the concepts mentioned by Verganti, this meaning may be considered first-level innovation, being the main factor in the development of an emotional link that triggers the intention of use by the students. 
Table 1. Comparison between Descomplica and traditional courses.

\begin{tabular}{lll}
\hline & \multicolumn{1}{c}{ Traditional Courses } & \multicolumn{1}{c}{ Descomplica } \\
\hline Value Strategy & Focus on the desire for the brand & Focus on the student experience \\
Classes & Good content transmission & Offer a good entertaining experience \\
& & Good content transmission \\
Content & $\begin{array}{l}\text { Closed, strategy focused on the valorization of } \\
\text { the service restricted to a select group of payers }\end{array}$ & $\begin{array}{l}\text { Democratic, strategy focused on as many } \\
\text { students as possible }\end{array}$ \\
$\begin{array}{l}\text { Meaning for the users } \\
\text { The 'why' of consumption }\end{array}$ & I need it to be approved & $\begin{array}{l}\text { I need it to be approved and this tool is my } \\
\text { opportunity to reach this goal }\end{array}$ \\
\hline
\end{tabular}

Note. Source: Prepared by the authors.

The data collected from the interviews with managers revealed that there was no collective meaning implementation strategy supported by structured methodologies, or by robust theoretical concepts. However, all managers recognized the purpose that guides Descomplica's strategy and actions. This alignment adheres to the role that purpose plays in meaning creation in Verganti and Öberg's (2013) model. The role purpose played can explain why Descomplica did not use, at the time the field research occurred, freelancer teachers, but only contract teachers with skills and capabilities associated with Marco's idea of education as an opportunity for all.

Therefore, we can say that the meaning strategy emerged from a heuristic process that engaged teachers to Descomplica's purpose of establishing emotional ties with students. According to data interpretation, a good part of this 'opportunity' perception is developed through the trust in the content quality, the autonomy to customize their studying routine, and the use of a more humanized, funny, and less mechanical methodology in the interaction with the students. The application of the meaning creation process as proposed in Verganti and Öberg (2017) can help understand the meaning strategy that emerged.

Based on the taxonomy of Johansson-Sköldberg et al. (2013), we can say that designerly thinking helped Descomplica's strategy in two ways. Firstly, by promoting a radical innovation in the meaning of formal education to attract and retain young students. For instance, the epiphany moments experienced by users, when they suddenly understand a subject usually considered by them exceedingly difficult or boring. Secondly, by using DT as an incremental innovation strategy to continuously evaluate students' user experience, promoting changes that maintain their emotional connections to Descomplica.

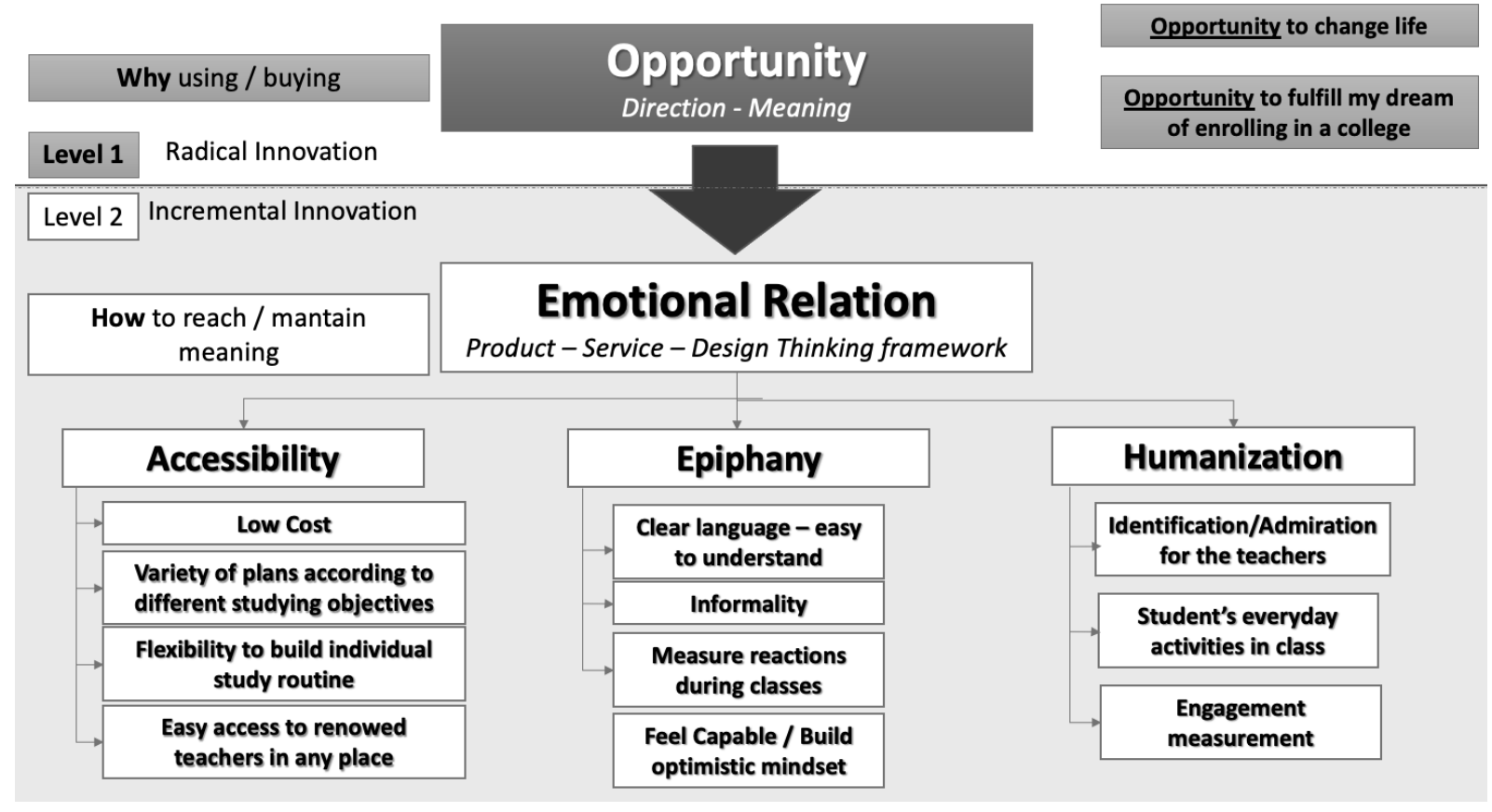

Figure 1. Levels of innovation.

Source: Prepared by the authors. 


\section{Meaning creation process}

\section{Awakening}

According to the collected data, the meaning of the company was created by its founder and former CEO. This fact is aligned with the model of Verganti and Öberg (2013), who recommend that in radical meaning innovations, the direction or purpose of the company is created by its main executive's perceptions and ideas. It is important to say that none of the interviewed executives knew exactly how the purpose of the company was created, but all of them reported that it was Marco's (founder/CEO) idea. In other words, the data collected with the managers shows that the meaning proposed by them is to create an opportunity for the users to enroll in a college. "For a very big margin, it means something that revolves around opportunity and hope. Mainly because many teachers here still work, or used to work, in expensive institutions... No doubt, many of our students would not be able to pay for a course that counts with teachers like ours. Therefore, there is a matter of opportunity, which maybe is the first feeling that the student has" (marketing manager and geography teacher).

\section{Pre-emptying}

Even though the findings showed that the executives did not participate in the creation of the meaning, it was inferred, due to the language, informality, and heterogeneity of the words used during their response that, on some scale, all of them pre-empted their paradigms to build a logic meaning of Descomplica. The answers mostly indicate the same meaning, but in their own words: to offer an opportunity for people to transform their life.

"Descomplica's clear purpose is to make the difference in the life of people, so that they can enroll in a college, to get better grades ... To correct a distortion, a big perversity in the Brazilian educational system" (marketing and operations $\mathrm{VP})$.

"... And then we jump a few social steps when we manage to put the guy to study at a level good enough to pass the exam for a federal university. So, this feeling of big gratitude is not only from the student but also from his family" (marketing manager and geography teacher).

"We have bizarre statements from students who lived in the Maranhão countryside, there was a library in the city, the only place with internet, and the boy went there to study and passed the college admission exams. This is very touching! You make the difference in someone's life, someone who is not attended" (marketing and audiovisual production manager).
The interviews with managers and teachers attest to the fact that it is common to build a feeling of admiration by students for teachers. According to these interviewees, this admiration is developed from a cycle of frequent feelings of epiphany and fun when interacting with the tool. "The guy has to think: 'Wow, I never understood that!' It is the feeling of epiphany that makes him a fan and always follows classes. So, if you do not have content, you do not last. You can make a cool image, whatever you want to do! If the guy does not have that feeling of epiphany he does not continue, because whoever is there wants to, and that is a big difference. And fun involves it all, not just the language" (marketing manager and geography teacher).

These findings support the existence of a meaning strategy but did not contribute to identifying how the meaning was created, although it is experienced as a symbolic value by managers and teachers. The process of 'auto-reflection' described in this phase can also support the evidence that the managers embodied (last phase of the meaning process of the research methodology) the meaning.

\section{Criticizing}

None of the executives interviewed mentioned any practice of collecting criticisms from members or interpreters outside of the organization as expected in this phase of the methodology proposed by Verganti and Öberg (2017). The only feedback they collected was from its users and managers. This strategy goes along with incremental innovation practices (Dell'Era \& Verganti, 2007). Since the practice of collecting criticism is carried out exclusively with internal stakeholders, the interview data do not provide evidence that Descomplica completely follows the phase of criticizing of the meaning process as defined in the methodology proposed by Verganti and Öberg (2017).

However, as the funding process from sources like seed money or private equity escalate, it is expected that the criticizing process by external stakeholders intensifies, which could reflect in greater interference in Descomplica's strategy, as seems to be the case of Descomplica's decision to enter in undergraduate and professional graduate programs ('Pós-graduação lato sensu') in 2020.

\section{Embodying}

There is evidence of a successful embodying strategy. This fact was inferred since, although none of the interviewed executives have participated in the creation of the meaning, they all knew and expressed the same meaning when describing the purpose of Descomplica. From these assumptions, the embodying of Descomplica's meaning in the team happened during the recruiting phase, or after 
hiring. "There is a lot of the way Marco teaches a class, his classes were always very funny. If you search Marco's live classes on YouTube when he was a teacher in conventional courses you will see a little bit of this, and he taught physics. And he recruited teachers to become members of the Descomplica team; these teachers had to have a profile like his, and a pedagogic strategy was created based on this. It was not thought and planned first and executed later. Things just happened this way" (marketing and operations VP).

\section{Incremental innovations}

To ensure the meaning, the gathered data indicated that Descomplica has its own methodology of teaching and interacting with its students. Even though all the interactions with the user were virtual, the company constantly searched for the humanization of the teachers, turning them not into an authority figure, but partners capable of providing learning in a fun, pleasant, simple, and affordable way.

The collected data revealed that the company only receives criticisms from its users. These feedbacks are collected and measured with tools common in the digital marketing and e-commerce market routines. Considering user's opinions to innovate goes along with the description of incremental innovation as described in UCD methodologies. The following quote shows this possible association between Descomplica proposed meaning and its incremental innovation practices: "It got quality content in a funny format (way), and when you put these two together ... We joke: We are a social platform like Facebook that offers quality education like Harvard, this is the joke! With high-level productions and entertainment, like Netflix, and still speaking an agile language and connected to youngsters, like Snapchat and Stories. Then you put together an agile and connected language, and quality education, it becomes ... High-level production and entertainment, inside a social environment, this is Descomplica, and this will engage people" (partner, teacher, and head of education and operations).

The coding process also allows verifying some co-occurrences. All the statements classified as OPPORTUNITY (for moments when the interviewee reported that Descomplica's proposal was explicitly opportunity), and PURPOSE (used for all moments when the respondents defined the purpose of Descomplica), there was a concomitance in all codes linked to the main constructs that drive the actions inside the company (Figure 2 shows how often). In other words, whenever managers defined Descomplica's meaning, they used reports aligned with accessibility, epiphany, and humanization.

\section{Co-occurance of constructs}

\begin{tabular}{|l|l|c|c|}
\cline { 3 - 4 } \multicolumn{1}{c|}{} & Opportunity & Purpose \\
\hline ACCESSIBILITY & & 9 & 4 \\
\hline CPIPHANY & Cheap & 3 & 1 \\
\hline Flexibility & 3 & 8 \\
\hline Quality Content & 3 & 13 \\
\hline HUMANIZATION & Epiphany & 8 & 17 \\
\hline Pleasant Class & 6 & 15 \\
\hline Fun & 4 & 15 \\
\hline Humanization & 8 & 20 \\
\hline Opportunity & 0 & 14 \\
\hline
\end{tabular}

Figure 2. Co-occurrences of constructs and purpose. Source: Prepared by the authors.

When considering the socio-economic profile and the scholarly background of these students in elementary education, the sample of responding students showed two profiles. Some students have always studied in private schools, likely from medium- or upper-income classes, who could pay good preparatory courses for the college admission exams, and students with an opposite socioeconomic background. Besides, some students opt for disputed graduate courses.
There are different levels of adherence to the perception of meaning between these groups. Students from public schools and students who opted for disputed courses seem to develop a bigger emotional relationship with the company than the private school students. It was possible to see that private school students used Descomplica as a complement to the content provided by their school, or even to be aware of the content to which their competitors had access. 


\begin{tabular}{|c|c|c|c|c|c|c|}
\hline & \multicolumn{5}{|c|}{ Degree of meaning per category } & \multirow{4}{*}{ OPPORTUNITY } \\
\hline MEANING & & Description of meaning & $\begin{array}{l}\text { Public } \\
\text { School }\end{array}$ & $\begin{array}{l}\text { Opting for } \\
\text { disputed } \\
\text { courses }\end{array}$ & $\begin{array}{l}\text { Private } \\
\text { School }\end{array}$ & \\
\hline \multirow{3}{*}{$\begin{array}{l}\text { Reason to sign in } \\
\text { (purpose of the } \\
\text { purchase) }\end{array}$} & 1 & Opportunity to have access to the best teachers and content & STRONG & STRONG & Low & \\
\hline & 2 & Opportunity to level the learning with competitors & STRONG & STRONG & MEDIUM & \\
\hline & 3 & Accessible (price) & STRONG & STRONG & STRONG & ACCESSIBILITY \\
\hline \multirow{3}{*}{$\begin{array}{c}\text { Generation } \\
\text { Characteristics } \\
\text { (Identity with the } \\
\text { service) }\end{array}$} & 4 & Autonomy / Flexibility for studying & STRONG & STRONG & STRONG & \multirow[b]{2}{*}{ EPIPHANY } \\
\hline & 5 & $\begin{array}{c}\text { Organization (teach how to study at home, study guide, } \\
\text { organized content) }\end{array}$ & STRONG & STRONG & STRONG & \\
\hline & 6 & Pleasant class (didactics, intimate language, funny) & STRONG & STRONG & STRONG & \\
\hline \multirow{7}{*}{$\begin{array}{c}\text { Feeling } \\
\text { (Emotional relationship) }\end{array}$} & 7 & Trust & STRONG & STRONG & STRONG & \\
\hline & 8 & Availability (easy contact and rapid answers) & STRONG & STRONG & MEDIUM & \\
\hline & 9 & Welcoming & STRONG & STRONG & Low & \multirow{5}{*}{ HUMANIZA } \\
\hline & 10 & $\begin{array}{l}\text { Family (group feeling, motivational discourses, being with } \\
\text { other people in the same situation) }\end{array}$ & STRONG & STRONG & Low & \\
\hline & 11 & Fan (admiration) & STRONG & MEDIUM & Low & \\
\hline & 12 & Fulfill a dream (recognize as to make feasible) & STRONG & MEDIUM & Low & \\
\hline & 13 & Essential / Vital & STRONG & MEDIUM & Low & \\
\hline
\end{tabular}

Figure 3. Levels of adherence between user groups.

Source: Prepared by the authors.

In Figure 3, one can see the construction of a bigger emotional link tied to the 'humanization' by the public school group, followed by the group of students who opted for disputed courses. The statements made by students belonging to these groups are more emotional, showing that the company is their hope for reaching their goals. It can be highlighted that this emotional link is formed after the subscription, during the use. What motivates a decision to subscribe in these two groups is mainly the autonomy to customize their studying routines, strongly supported by the accessible price, trust in the content, and identification with the language in the videos. The epiphany construct, which emerged from teachers' narrative regarding Descomplica's purpose, can also be perceived in a student response.

"... and I chose to continue with Descomplica because it is not just an online course, they embrace you, I felt the teachers and teaching assistants closer than in live classes, that's their differential. What I like a lot in Descomplica is that they are like a family, they make us feel at home, and we learn a lot more like that. I did not understand many things before, but I could understand with them, and that, by definition, is what they are for me" (AL. student. Category: private school, opting for a disputed course).
"Descomplica saved my life, they are like a light amid the darkness, because if it were not for them, I would not have another opportunity to be approved, they had incredibly good material, done in a marvelous way, they allowed me to take advantage most of the time, something that cheap preparatory courses do not have, and I could not afford an expensive one ... I would not be approved if not for Descomplica; there was no other way" (IZ. student. Category: public school).

In the group of public school students and in the group of students who opted for disputed courses, reports qualifying Descomplica as 'welcoming' and 'family' stand out. Evidence showed a very intense dedication, as they were more interested in the college admission exams than other students. There were reports of students who were trying college admission for the second or third consecutive year, and, due to being more involved, they seem to build a bigger emotional link. When they described the meaning of Descomplica, it is like they were talking about family, like a group that welcomes, supports, and motivates. Even though Descomplica is an online intermediary, some students refer to teachers as close heroes: "Descomplica is something vital in my life, there is a lot of support and I became awfully close to the teachers and employees... It is like I was part of 
what Descomplica is today" (JU. student. Category: public school, opting for a disputed course).

Regarding private school students, the meaning seems to be restricted to aspects of autonomy, trust in the content, identification with the language used in the videos, and the need for getting leveled with their competitors. The development of more sentimental links was not strong in this category, even after long periods of use. It must be highlighted that the meaning of 'leveling' for this group seems to be different from the meaning of 'leveling' for the group of public school students.

There are signs that these students perceive not to hold the exclusivity for quality content once Descomplica allowed access to good content to any students subscribing to its classes. The meaning of 'leveling' would then be tied to a ground zero, the minimum one is supposed to know, as if knowing the content made available by Descomplica was a premise to be successful in the college admission exams. On the other hand, for public school students, 'leveling' is associated with the possibility of becoming competitive.

“... I thought that as everybody was watching Descomplica, or at least my competitors had access to Descomplica, theoretically I had to know at least all of that to start from the same point as they do, whatever extra knowledge I had would be a differential..." (BE. student. Category: private school).

"Because you don't have to pass an exam to access Descomplica... You don't need an exam, you just subscribe to it and that's it. They say they don't know who is on the other side of the screen, what is the education level of these people, so they try to level these people, it's a hard and arduous job” (LA. student. Category: public school).

Regarding the meaning of Descomplica developed over the users, different levels of meaning may be seen according to the groups mentioned earlier. They vary from a love and admiration relationship to the identification of a good education tool.

All respondents mentioned Descomplica as an enabler of autonomy for studying, being this one of the main factors considered when they decide to subscribe to the platform. The access to information became timeless with the internet, which allows people to have a more flexible routine. According to the users, Descomplica not only makes available the content in an organized way, with a proposed roadmap for studying, but it also develops the user's capability to be a student in the digital age. Other company's characteristics add to the valorization of this meaning, such as trust in the content, accessible price, and content organization in the platform.
The other meaning clearly shown is the 'pleasure in studying,' strongly related to the language employed in video classes. All students stated that Descomplica's videos are usually more pleasant than traditional live classes. And, moved by the feeling of pleasure in learning, the students report living a learning experience aligned with entertainment.

The respondents belonging to the group from public schools evidenced a stronger alignment to the meaning proposed by Descomplica. This is the group where the company gets more return on its proposal for meaning: all respondents showed a bigger emotional link with Descomplica. That type of feeling is expressed in the following narrative: "This is what I need, to be prepared, to succeed in the exams, to fulfill my dream, but also with a plus, not just the course, because I can meet people who are in the same level as me, and to be a better person" (C.A. student. Category: public school).

Anyway, regardless of the category, it is possible to infer that the students see the company as a tool to improve the assimilation of the content of the educational system of which they are part. The advocacy to replace official schools for Descomplica was not identified in the interviews, but as a complement to the goal of passing the college admission. We did not identify in students' narratives any explicit mention to develop the capabilities associated with neoliberal capitalism, such as entrepreneurship. However, we did notice a central concern to win the battle of achieving a high mark on the ENEM (Brazilian National High School Examination), which can be connected to the meritocracy construct.

\section{Managers' perception versus users' perception}

Figure 4 depicts the moment where the perception of meaning begins (starting from a trust relationship) and summarizes the comparison between the meaning proposed by Descomplica and the user's perceptions of that meaning (in different levels).

The data collected with the students' narratives showed evidence of an emotional connection between users and Descomplica. A few statements explicitly contained meanings as 'loving' or 'being a fan of' the company. The existence of an emotional relationship shows that Descomplica signifies the challenge to absorb the educational content to pass exams in a unique way. These evidences are partially in accordance with the concepts of meaning innovation described by Verganti and Öberg (2013), where meaning creation precedes a strategy of innovating by solutions. 


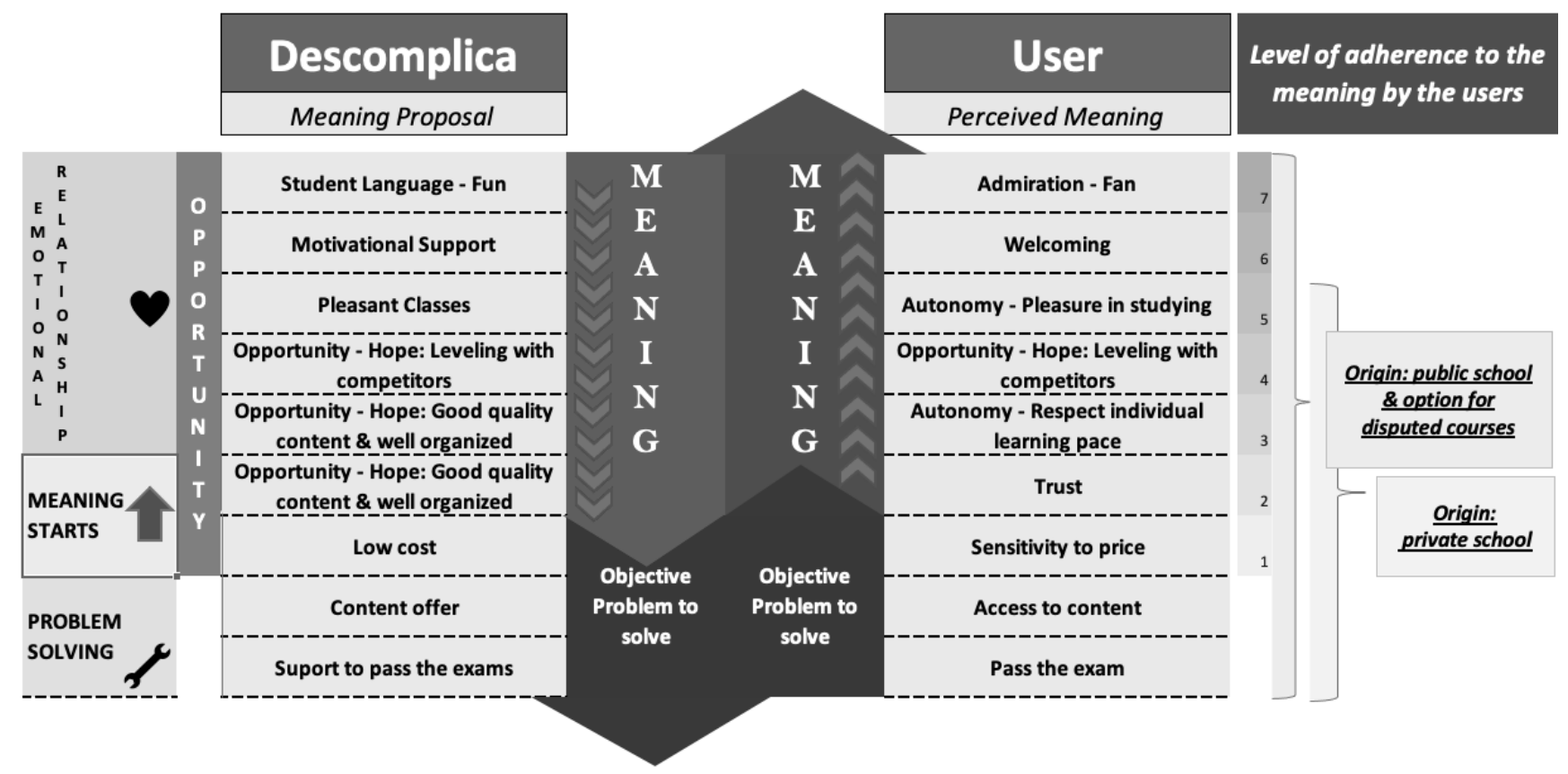

Figure 4. Summary: proposed meaning and perceived meaning.

Source: Prepared by the authors.

We collected evidence that the meaning innovation aims at producing a self-reliant epiphany feeling by using a ludic - almost naïve - communication strategy to connect to students' emotions. Descomplica's meaning strategy is rooted in its founder's vision to democratize education. However, the narratives and documents collected to analyze the case did not evidence the intention to develop students' critical thinking regarding business-as-usual assumptions.

As its recent decision to offer undergraduate and postgraduate regular courses suggests, Descomplica's business model seemed to be designed to answer the meritocracy battle of contemporary capitalism by teaching the capabilities demanded by the market. It is also clear that, as EdTech acting also in regulated markets, Descomplica leveraged the potential to promote disruptive innovation in the education sector. Even though meaning innovation, in the sense attributed by Verganti and Öberg (2013), proved to be effective from the point of view of Descomplica's strategic interests, it cannot be considered a radical innovation in the sense attributed by SOI studies.

\section{CONCLUDING REMARKS}

This study had the purpose of verifying the practice of meaning innovation strategy, as contextualized in the DT literature, in a digital preparatory course technology platform. The authors of this article understand, from the coding process shown in the previous section, that the alignment of Descomplica's proposal was identified, at least to some aspects of the meaning innovation strategies as defined by Verganti and Öberg (2013). Table 2 shows how each category of questions in the survey roadmap contributed to the achievements of the objectives of this study.

Table 2. Summary of the objectives reached according to the phase in the survey roadmap.

\begin{tabular}{|c|c|c|c|}
\hline Gathered Data on Phases & $\begin{array}{l}\text { Primary Objective } \\
\text { Identify alignment with meaning }\end{array}$ & $\begin{array}{l}\text { Secondary Objective } 1 \\
\text { Identify the meaning creation process }\end{array}$ & $\begin{array}{c}\text { Secondary Objective } 2 \\
\text { Identify synergies between the } \\
\text { proposed meaning and the perceived } \\
\text { meaning }\end{array}$ \\
\hline Awakening & No & No & No \\
\hline Pre-emptying (think / reflect) & Yes & No & Yes \\
\hline Criticizing & Yes & No & Yes \\
\hline Embodying (congregate) & Yes & No & Yes \\
\hline Interviewed Students & Yes & No & Yes \\
\hline
\end{tabular}

Note. Source: Prepared by the authors. 
The evidence collected in the discussion advances what is already present in the current literature on technological innovation enabled by digitization, presently called digital transformation, analyzing it from the theory and practice of meaning innovation. This interdisciplinary approach allowed investigating the development of subjectivities due to the virtualization of production and of relationships that resulted from the disruptive innovations triggered by online educational service platforms, an interwoven identified as a gap in the investigated scientific literature.

In regard to the secondary objective 1 , the mapping of Descomplica's meaning creation process could not be analyzed, since we found no evidence that the interviewed managers took part in this process. The survey roadmap was inspired in a workshop in which the objective was to make executives identify, create, or reconfigure the meaning in their companies, and the starting point was the premise that these executives would be the agents responsible for this kind of innovation. However, in managers' narratives, it was possible to identify the existence of a proposal to create an emotional relationship between the company and its users, focused on the creation of an opportunity, but they could not explain how this proposal was idealized.

By interpreting students' narratives, it was possible to identify the existence of a relevant and significant emotional relationship between them and Descomplica. This evidence contributes to reaching the secondary objective 2. It is important to highlight that, even though the data gathered indicated synergy between the proposed and the perceived meanings, there were different levels of adherence according to the users' background. There was a higher synergy regarding the group of students from lower social classes in comparison to the group of students from higher social classes. On the other side, the meanings of 'pleasure in learning' and 'autonomy' for studying, aspects of the meaning 'opportunity,' were valued by all users.

Considering the exploratory character of this study, the results allow for additional thinking, because it was seen that, on some scale, Descomplica transforms people's lives. Nevertheless, we can think about the influences that these elements may bring to the post-industrial education. The evidence of this study shows the student's unanimous valorization of the 'autonomy' to take their own learning pace. This, together with the type of language used, shows a feeling of 'pleasure in learning' by the users. Maybe, what the company is doing is just respecting each student's individuality, not imposing pace, hours, attitude, standards, or rules of conduct. These control characteristics have always been applied in a school environment since the industrial age.

As is usual in design thinking innovation strategies, a demand-pull approach may be capturing students' perceptions of education in each socio-technical system. Evidence captured in this case study does not allow us to conclude that online educational organizations, even using meaning innovation, are providing all the knowledge students need to face the challenges of human societies in the next decades. Since the introduction of technologies like artificial intelligence and augmented reality is only at the early stages in educational institutions, we conclude this study by reinforcing the urgency to discuss, from organizational and educational theoretical perspectives, the impacts of online methods in Brazilian students' perceptions and behaviors.

\section{Suggestions for future research}

Socio-technical systems address the co-evolution of social behavior and technological artifacts. Presently, this co-evolution is strongly influenced by the advancement of digital transformation. Some of the evidence obtained in this study does show a potential influence of such changes in education. Therefore, we suggest some questions to be treated in future studies. Would the model applied by Descomplica be a sign of the necessity to reevaluate the meaning of education for young students? Future studies, by using the insights obtained in this survey, could validate this relationship with a quantitative survey, using a larger sample of students. Could Descomplica be showing the possibility of online education platforms going beyond the teaching capabilities guided by the demands of the job market, but also to induce critical thinking? Therefore, it is critical to research Descomplica's educational content to evaluate if students, mainly from low-income strata, will be able to apply for the scarce, segmented, selective job market that tends to emerge in the 4th industrial revolution. Evidence suggests that the meaning strategy in DT is still firm centered. As such, meaning can change users' subjectivity without changing business-as-usual assumptions. Thus, does DT theory also need to reframe the meaning of the meaning construct, including the ethical dimension of sustainability challenges? The triangulation of evidence obtained by the application of other innovation theoretical frameworks, such as paradigmatic innovation or SOI, can help deepen the study of these issues. 


\section{REFERENCES}

Adams, R. J., Jeanrenaud, S., Bessant, J., Denyer, D., \& Overy, P. (2015). Sustainability-oriented innovation: A systematic review. International Journal of Management Reviews, 18(2), 180-205. https://doi.org/10.1111/ijmr.12068

Adams, R.J., Smart, P., \& Huff, A.S. (2017). Shades of grey: Guidelines for working with the grey literature in systematic reviews for Management and Organizational Studies. International Journal of Management Reviews, 19(4), 432-454. https://doi.org/10.1111/ijmr.12102

Allen, S., Cunliffe, A.L., \& Easterby-Smith, M. (2019). Understanding sustainability through the lens of ecocentric radical-reflexibility: Implications for management education. Journal of Business Ethics, 154, 781-795. https://doi.org/10.1007/s10551-016-3420-3

Battistella, C., Biotto, G., \& Toni, A. F. (2012). From design driven innovation to meaningstrategy.ManagementDecision, $50(4)$, 718-743. https://doi.org/10.1108/00251741211220390

Brown, T. (2008). Design thinking. Harvard Business Review, 86(6), 84-92. Retrieved from https://hbr.org/2008/06/design-thinking

Cohen, W. M., \& Levinthal, D. A. (1990). Absorptive capacity: A new perspective on learning and innovation. Administrative Science Quarterly, 35(1), 128-152. https://doi.org/10.2307/2393553

Cornelissen, J., \& Cholakova, M. (2019). Profits uber everything? The gig economy and the morality of category work. Strategic Organization. https://doi.org/10.1177\%2F1476127019894506

Creswell, J. (2003). Research design: Qualitative, quantitative and mixed methods approaches (2 ed.). London: Sage Publications.

De Goey, H., Hilletofth, P., \& Eriksson, L. (2019). Design-driven innovation: A systematic literature review. European Business Review, 31(1), 92-114. https://doi.org/10.1108/EBR-09-2017-0160

Dell'Era, C., \& Verganti, R. (2010). Collaborative strategies in design-intensive industries: Knowledge diversity and innovation. Long Range Planning, 43(1), 123-141. https://doi.org/10.1016/j.lrp.2009.10.006

Dell'Era, C., \& Verganti, R. (2007). Strategies of innovation and imitation of product languages. Product Development o Management Association, 24(6), 580-599. https://doi.org/10.1111/j.1540-5885.2007.00273.x

Denzin, N., \& Lincoln, Y. (1994). Handbook of qualitative research. London: Sage Publications.

Dosi, G. (1982). Technological paradigms and technological trajectories: A suggested interpretation of the determinants and directionsoftechnicalchange. ResearchPolicy, 11(3), 147162. https://doi.org/10.1016/0048-7333(82)90016-6

Eisenhardt, K. M. (1989). Building theories from case study research. Academy of Management Review, 14(4), 532-550. https://doi.org/10.5465/amr.1989.4308385
Elms, H., Brammer, S., Harris, J. D. \& Phillips R. A. (2010). New directions in strategic management and business ethics. Business Ethics Quarterly, 20(3), 401-425. https://doi.org/10.5840/beq201020328

Fagerberg,J.,Fosaas, M., Bell,M., \&Martin, B.R.(2011).Christopher Freeman: Social science entrepreneur. Research Policy, 40(7), 897-916. https://doi.org/10.1016/i.respol.2011.06.011

Figueiredo, P. N. (2009). Gestão da inovação: Conceitos, métricas e experiências de empresas no Brasil. Rio de Janeiro: LTC.

Freeman, C. (1974). The economics of industrial innovation. Harmondsworth: Penguin.

Freeman, C., \& Soete, L. (2007). The economics of industrial innovation (3 ed.). London: Frances Pinter.

Frenken, K., Vaskelainen, T., Fünfschilling, L., \& Piscicelli, L. (2018). An institutional logics perspective on the gig economy. SocArXiv. https://doi.org/10.31235/osf.io/uqn9v

Friese, S. (2014). Qualitative data analysis with ATLAS.ti (Vol. 2). London: Sage Publications.

Gantman, E. R. (2019). Capitalism, social privilege, and managerial ideologies. London: Routledge.

Gröschl, S., \& Gabaldon, P. (2018) Business schools and the development of responsible leaders: A proposition of Edgar Morin's transdisciplinarity. JournalofBusiness Ethics, 153(1), 185-195. https://doi.org/10.1007/s10551-016-3349-6

Griffith, R., Lee, S. \& Straathof, B. (2017). Recombinant innovation and the boundaries of the firm. International Journal of Industrial Organization, 50, 34-56. https://doi.org/10.1016/j.ijindorg.2016.10.005

Guba, E., \& Lincoln, Y. (1989). Fourth generation evaluation. London: Sage Publications.

Hesse, M., Dann, D., Braesemann, F., \& Teubner, T. (2020). Understanding the platform economy: Signals, trust, and social interaction. Proceedings of the Hawaii International Conference on System Sciences, Maui, Hawaii, USA, 53.

Johansson, U., \& Woodilla, J. (2009). Creating a synergistic dialogue among design thinking, strategy, and innovation. Design Research Journal, (2), 29-33. Retrieved from https:/gup.ub.gu.se/publication/188848?lang=en

Johansson-Sköldberg, U., Woodilla, J., \& Çetinkaya, M. (2013). Design thinking: Past, present, and possible futures. Creativity and Innovation Management, 22(2), 121-146. https://doi.org/10.1111/caim.12023

Kim, C. W., \& Maubourgne, R. (2005). Blue ocean strategy: From theory to practice. California Management Review, 47(3), 105-121. https://doi.org/10.1177\%2F000812560504700301

Kim, N., Park, Y., \& Lee. D. (2019). Differences in consumers' intention to use on-demand automobile-related services in accordance with the degree of face-to-face interactions. Technological Forecasting and Social Change, 139, 277-286. https://doi.org/10.1016/j.techfore.2018.11.014 
Kolko, J. (2015). Design thinking comes of age. Harvard Business Review, (September 2015), 66-71. Retrieved from https://hbr.org/2015/09/design-thinking-comes-of-age

Kosheleva, O., Viera, J. Jr., \& Kreinovich, V. (2019). From gig economy to gig education. Mathematical Structures and Modeling, 2(50), 107-111. Retrieved from https:// cyberleninka.ru/article/n/from-gig-economy-to-gigeducation

Krippendorff, K. (1989). On the essential contexts of artifacts or on the proposition that 'design is making sense (of things)'. Design Issues, 5(2) 9-39. https://doi.org/10.2307/1511512

Lima, A. (2020, April). Para CEO da Faculdade Descomplica, isolamento social pode mudar percepção sobre educação digital. LABS - Latin America Business Stories. Retrieved from https://labs.ebanx.com/pt-br/artigos/tecnologia/paraceo-da-faculdade-descomplica-isolamento-social-podemudar-percepcao-sobre-educacao-digital/

Magistretti, S., Dell'Era, C., \& Verganti, R. (2020). Searching for the right application: A technology development review and research agenda. Technological Forecasting and Social Change, 151, 119879. https://doi.org/10.1016/j.techfore.2019.119879

McCraw, T. K. (2007). Prophet of innovation: Joseph Schumpeter and creative destruction. Cambridge, MA: Harvard University Press.

Means, A. J. (2018). Platform learning and on-demand labor: Sociotechnical projections on the future of education and work. Learning, Media, and Technology, 43(3), 326-338. https://doi.org/10.1080/17439884.2018.1504792

Miles, M., \& Huberman, M. (1994). Qualitative data analysis: An expanded sourcebook (2 ed.) California: Sage Publications.

Mowery, D., \& Rosenberg, N. (1979). The influence of market demand upon innovation: A critical review of some recent empirical studies. Research Policy, 8(2), 102-153. https://doi.org/10.1016/0048-7333(79)90019-2

Nonaka, I., \& Takeuchi, H. (1995). The knowledge-creating company: How Japanese companies create the dynamics of innovation. New York: Oxford University Press.

Norman, D. A., \& Verganti, R. (2014). Incremental and radical innovation: Design research vs. technology and meaning change. Design Issues, 30(1), 78-96. https://doi.org/10.1162/DESI a 00250

Olga, K., Julian, V., \& Vladik, K. (2019). From gig economy to gig education. Математические структуры $u$ моделирование, 2(50), 107-111.

Organisation for Economic Co-operation and Development. (2005). Oslo manual: Guidelines for collecting and interpreting innovation data (3 ed.). Paris: OECD.

Painter-Morland, M., Demuijnck, G., \& Ornati, S. (2017). Sustainable development and well-being: A philosophical challenge. Journal of Business Ethics, 146, 295-311. https://doi.org/10.1007/s10551-017-3658-4
Ratten, V., \& Usmanij, P. (2020). Entrepreneurship education: Time for a change in research direction? The International Journal of Management Education, 19(1), 100367. https://doi.org/10.1016/j.ijme.2020.100367

Ruvolo, J. (2015, July). Is for-profit the future of education in Brazil? Tech Crunch. Retrieved from https://techcrunch. com/2015/07/19/is-for-profit-the-future-of-educationin-brazil/

Savage, P., Geissdoerfer, M., Kharrazi, A., \& Evans, S. (2019). The theoretical foundations of sociotechnical systems change for sustainability: A systematic literature review. Journal of Cleaner Production, 206, 878-892. https://doi.org/10.1016/j.jclepro.2018.09.208

Schumpeter, J. A. (1934). The theory of economic development. Cambridge, MA: Harvard University Press.

Simon, A. H. (1969). The sciences of the artificial (3 ed.). Cambridge, MA: MIT Press.

Siqueira, R., \& Pitassi, C. (2016). Sustainability-oriented innovations: Can mindfulness make a difference? Journal of Cleaner Production, 139, 1181-1190. https://doi.org/10.1016/j.jclepro.2016.08.056

Teece, D. (2010). Business model, business strategy and innovation. Long Range Planning, 43(2-3), 172-194. https://doi.org/10.1016/j.lrp.2009.07.003

Teece, D. J., \& Linden, G. (2017). Business models, value capture, and the digital enterprise. Journal of Organization Design, 6(1), 8. https://doi.org/10.1186/s41469-017-0018-x

The Christensen Institute. (2021, March). What is disruptive innovation? Retrieved from https://www.christenseninstitute.org/disruptive-innovations/

Utterback, J. (1994). Mastering the dynamics of innovation: How companies can seize opportunities in the face of technological change. Boston, MA: Harvard Business School Press.

Vallas, S., \&Schor,J. B. (2020). What do platformsdo? Understanding the gig economy. Annual Review of Sociology, 46, 273-294. https://doi.org/10.1146/annurev-soc-121919-054857

Verganti, R. (2006). Innovating through design. Harvard Business Review, 84(12), 114-123. Retrieved from https://hbr.org/2006/12/innovating-through-design

Verganti, R. (2008). Design, meanings, and radical innovation: A metamodel and a research agenda. Journal of Product Innovation Management, 25(5), 436-456. https://doi.org/10.1111/j.1540-5885.2008.00313.x

Verganti, R., \& Öberg, Å. (2013). Interpreting and envisioning - A hermeneutic framework to look at radical innovation of meanings. Industrial Marketing Management, 42(1), 8695. https://doi.org/10.1016/j.indmarman.2012.11.012

Verganti, R. (2016). The innovative power of criticism. Harvard Business Review, 94(1), 89-95. Retrieved from https://hbr.org/2016/01/the-innovative-power-of-criticism

Verganti, R. (2017). Overcrowded: Designing meaningful products in a world awash with ideas. Cambridge: The MIT Press. 
Verganti, R., \& Öberg, Å. (2017). Innovation in your Box: Why Meaning - not ideas - is the key to success. ESBRI Entrepreneurship and small business Research Institute. Retrieved from http://www.esbri.se/forelasning tv visae. asp?id=217156653

\section{Authorship}

\section{Raphael Lobo}

Instituto Brasileiro de Mercado de Capitais

Av. Pres. Wilson, no 118, Centro, 20030-020, Rio de Janeiro, RJ, Brazil.

E-mail address: raphael.lobo@gmail.com

(D) https://orcid.org/0000-0001-9762-3818

\section{Claudio Pitassi*}

Instituto Brasileiro de Mercado de Capitais

Av. Pres. Wilson, no 118, Centro, 20030-020, Rio de Janeiro, RJ, Brazil.

E-mail address: claudio.pitassi@gmail.com

(D) https://orcid.org/0000-0002-5720-0201

* Corresponding Author

\section{Funding}

The authors reported that there is no financial support for the research in this article.

\section{Conflict of Interests}

The authors have stated that there is no conflict of interest.
Vojak, B., Price, R., \& Griffin, A. (2012). Serial innovators: How individuals create and deliver breakthrough innovations in mature firms. Research-Technology Management, 55(6), 4248. https://doi.org/10.5437/08956308X5506899

\section{Authors' Contributions}

$\mathbf{1}^{\text {st }}$ author: conceptualization (equal); methodology (equal); formal analysis (lead); investigation (lead); visualization (equal).

$2^{\text {nd }}$ author: conceptualization (equal); methodology (equal); supervision (lead); validation (lead); writing - original draft (lead).

\section{Copyrights}

RAC owns the copyright to this content.

\section{Plagiarism Check}

The RAC maintains the practice of submitting all documents approved for publication to the plagiarism check, using specific tools, e.g.: iThenticate.

\section{Peer Review Method}

This content was evaluated using the double-blind peer review process. The disclosure of the reviewers' information on the first page, as well as the Peer Review Report, is made only after concluding the evaluation process, and with the voluntary consent of the respective reviewers and authors. 